\title{
Book Section
}

\section{The Anatomy of Antiliberalism}

Stephen Holmes (Cambridge, Mass.: Harvard University Press, 1993).

Stephen Holmes' The Anatomy of Antiliberalism should prove a welcome addition to the debate between communitarians and liberals. ${ }^{1} \mathrm{He}$ defines the antiliberal style of thought and distinguishes its critique of liberalism from that offered by Marxists. While Marxists focus on alienated labor and inequality in liberal societies, nonmarxist antiliberals attack the individualist and universalist values of liberal political theory and view the degree to which these values are realized in liberal societies as a moral tragedy. Holmes traces the continuity of central antiliberal ideas over the last two centuries and subjects them to critical examination. He also appraises the antiliberal reading of liberal political theory and provides convincing evidence that it is faulty. Any student of political theory should find Holmes' book valuable and pleasant reading. It is informative, lively, and contains sharp political analysis.

\section{Defining Nonmarxist Antiliberalism}

The first part of Holmes' book is devoted to an examination of several major antiliberal theorists. It is not intended as a history of antiliberal thought; Holmes fixes his attention on six figures whom he believes display the essential attributes of nonmarxist antiliberalism: Joseph de Maistre, Carl Schmitt, Leo Strauss, Alasdair MacIntyre, Christopher Lasch, and Roberto Unger. Undoubtedly the last four would object to being thrown in with Maistre and Schmitt, but Holmes aims to show that these writers, enamored of community and tradition, have neglected their intellectual forerunners. Holmes in fact does an admirable job of tracing the persistence of certain themes in antiliberal thought. The bases on which they reject liberalism displayed shared assumptions about human nature and society; their account of the "crisis" of liberal societies grounds social criticism in analysis of liberal political theory, as if liberal principles have been fully realized; their policy prescriptions are either vague, impracticable, or nonexistent. Holmes says of his project that:

I will have succeeded maximally if I convince the reader of nonmarxist antiliberalism's shortcomings.

I will have succeeded minimally if $I$ bring nonmarxist antiliberalism into focus as a unified subject for theoretical scrutiny and partisan debate. (xvi)

Holmes succeeds in illuminating the intellectual sources of nonmarxist antiliberalism, and he clarifies the questionable and sometimes disturbing views of social life and the individual that stand behind the critique of liberalism these writers present.

Holmes suggests that "antiliberalism is as much a mindset as a theory ... their enmity is typically lavished on individualism, rationalism, humanitarianism, rootlessness, permissiveness, universalism, materialism, skepticism, and cosmopolitanism"(5). The antiliberals adopt a common strategy in their approach to liberalism. First, they identify a 
our moral obligation. Holmes suggests that there is a logical gap in present-day antiliberal reasoning:

Why do our contemporary "communitarians" habitually treat "the social" as a moral obligation rather than an inevitable condition? Here is a partial response: the antiliberal style of reasoning, which seems illogical today, originally depended on theological premises that later dropped from sight. When no longer based on the idea of a divine injunction, however, the claim that man's sociality is morally binding becomes unintelligible". (17)

Schmitt derives a communal value from intergroup conflict. Group conflict lends direction and significance to the individual's life. Nationalism and war likewise give meaning to politics, and liberals thoroughly misunderstand the nature of politics. Politics is conflict between groups, not simply social interests or ideas, and it must be resolved by the destruction of one side rather than by compromise, as liberals mistakenly believe. Schmitt's claim that liberal democracies cannot survive in a dangerous world is, as Holmes notes, thoroughly unconvincing.

MacIntyre derives communal obligation via Aristotelian teleology. The function of a thing is its good; a good person is one who serves the community through performance of a function specified by the traditions of the community into which they were born. Holmes points to a flaw in MacIntyre's argument. MacIntyre holds that in fulfilling social roles the individual realizes the human essence, but this idea conflicts with his claim that liberalism is wrong in its foundational assumption of the abstract individual. It is also a problem for Maclntyre because his functional concept of the individual fails to "define the human telos apart from actual social institutions and concrete social demands" (103). The manner in which Holmes moves from Schmitt, the legal theorist of National Socialism, to the "soft" antiliberal MacIntyre is thought provoking. Because antiliberals reject universal values, there is no reasonable ground on which a "soft" antiliberal such as MacIntyre could categorically reject a Schmittian view of politics. MacIntyre's particularism provides no basis for defying the collective purpose of one's group. Duty to the group lends moral meaning to the individual's life, but this provides no foundation for duties to members of other groups. Liberal universalism can supply a justification for duties to other societies and their members, but antiliberalism cannot.

Holmes presents an incisive critique of communitarianism. Communitarians claim that liberalism fails to provide the social cohesion essential to human well-being; a deep, comprehensive moral consensus is a psychological and political necessity for a healthy community. Communitarians, however, "never provide sufficient detail about the national political institutions they favor to allow us to compare the advantages and disadvantages of illiberal community with the vices and virtues of the liberal societies we know" (178). They say nothing of minority rights and toleration of dissent, presumably because that would commit them to liberal principles. Political history discloses innumerable cases of attempts to establish the solidarity and consensus communitarians admire, and these have been terribly destructive. If community is an overriding value, what means are to be excluded for the sake of attaining it? The communitarians' quiet on this point may reflect 
the unwillingness of "soft" antiliberals to bite the bullet and accept the full implications of their political views. Liberals, on the other hand, have a clear position:

Unlike communitarians, liberals view community discriminatingly. Solidarity is good or bad, depending on its results. Group identity is morally welcome when it supports the universalistic distribution of individual rights to all individuals regardless of the place of birth, race, ethnic group, religion, gender, and so forth. It is unwelcome when it inhibits such a liberal distribution of rights. (297)

Liberals possess universalistic standards to evaluate collective goals, but communitarians do not. Moreover, the absence of a Maistrean theological premise haunts present-day communitarians: "From the uncontroversial premise that 'man is a social animal', communitarians draw the highly controversial conclusion that a warm and solidaristic social order is morally obligatory. But the inference is bogus. They deduce a 'value' from a 'fact' only by a conceptual slight of hand" (179). Communitarians also employ their primary fact in confused ways. They maintain that liberals are wrong in (allegedly) ignoring the social nature of individuals, but communitarians also hold that liberal societies have produced atomized individuals. They cannot have it both ways; people cannot be social and asocial simultaneously. "It is obviously contradictory to say that liberal individuals do not exist and that the ones who exist are excruciatingly unhappy" (182).

Antiliberals attack their opponents for weakening authority. Maistre sees liberalism as a revolt against the Divine authority vested in political institutions; Schmitt sees it as the triumph of a greedy and disloyal middle class. Strauss and MacIntyre blame the conflictual politics of modern democracies on the absence of firm authority. Antiliberals tend to admire the politics of ancient Greece and medieval Europe, but as Holmes points out, they do not explain why the political conflict which occurred in these political systems was superior to that which we experience today. Antiliberals seem unperturbed by the presence of liberal states that wield authority effectively; liberalism, they contend, must erode authority. While liberals maintain that authority can be rationally justified, antiliberals hold that it must be supported by myths, especially religious belief. Science, which antiliberals associate with liberal rationalism, is particularly destructive in this respect. From Maistre to MacIntyre and Lasch, antiliberals charge science with fostering materialism, hedonism and doubt. The scientific world view supposes that nature can be understood and mastered, and thus destroys the myths on which authority and community rely. As Holmes points out, the attack on science yields no policy prescriptions. No form of government has proven able to guide technological progress in a particularly desirable direction and, even if one dislikes the cultural impact of scientific inquiry, it is difficult to imagine bringing it to a halt.

Roberto Unger stands out among the antiliberals Holmes examines. The others argue that liberalism is deficient for destroying communal solidarity, but Unger argues that liberalism is too repressive. Holmes here introduces another means of categorizing antiliberals by dividing them into "communitarian conservatives" and "counterculture radicals" (141). Unger holds that liberalism dulls the aesthetic sense and stifles selfexpression. Liberal political thought, he contends, urges us toward the mundane and oppressively restricts our experience of life. Rule-bound liberal societies confine our 
freedom to act as we will. Unger's policy proposals are incongruous with his concerns about liberalism. He wants a highly responsive majoritarian democracy with powers to control investment decisions and break up concentrations of wealth. It is strange that Unger believes this will promote defiant self-assertion. As Holmes indicates, this sort of critique ignores liberal claims concerning the significance of autonomy and self-development found in Kant, J.S. Mill and Humboldt, among others. Not every liberal will hold, with Bentham, that push pins are as good as poetry, and marginal utility theory is not the centerpiece of liberal political thought. If liberal citizens prefer potato chips to Picasso, liberal political theory is not to blame. Holmes has a purpose in examining Unger, the countercultural radical, along with the communitarian conservatives.

Both sides have grasped one half of the truth, as it were, and jointly they cancel each other out. Together, they suggest a position close to commonsense. Liberalism is neither anarchical nor tyrannical. It is both more constricting than communitarian conservatives charge and less constricting than countercultural radicals claim. It is a philosophy of limits as well as a philosophy of freedom. It imposes important constraints on individuals, including prohibitions against violent self-help and against self-exemption from laws that should apply to all. But it also helps preserve the fragile institutional preconditions for personal choice as well as for the democratic correction of collective mistakes (142).

\section{Antiliberals fail to grasp liberal life and institutions, and they misunderstand liberal political thought.}

Antiliberals attack liberalism through the device of "antonym substitution" (253). Where liberals wanted competition rather than monopoly, for example, antiliberals say they favored competition over brotherly love. Antonym substitution is not necessarily a conscious strategy pursued by antiliberal writers, but it is a means by which they misunderstand and misrepresent liberal ideas. Antiliberals take liberal ideas out of the historical context in which they emerged and systematically pervert them. In particular, they misinterpret the liberal conception of the individual and the meaning of liberal constraints on power. Antiliberals assert, for example, that liberals assume human beings are naturally asocial. As Holmes notes, one need only look to liberal texts, such as Hume's social and ethical thought, for evidence to the contrary. Moreover, contractarian arguments, such as Locke's and Kant's, do not presuppose the existence of social atoms. A liberal can consistently maintain that individuals' purposes ought not to be subordinated to those of others, and thus demand consent (actual or hypothetical) to authority, without denying that human beings flourish only in society. Nor is liberalism essentially hedonistic and acquisitive, as antiliberals hold. Instead, property rights, by decentralizing power, facilitate the individual and group pursuit of non-economic goals. Antiliberals maintain that liberals despise authority and reject any notion of the common good. Liberals such as Madison and Smith, however, believe that "justice, self-rule, and the fruits of peaceful coexistence are all common goods. They are enjoyed by individuals, to be sure, but jointly, not atomistically" (200). The procedural and substantive limits on power that protect these values are the source of a liberal state's authority; liberalism and anarchism are distinct political theories. Liberal individualism does not, as antiliberals claim, constitute a rejection of the public sphere. In fact, Holmes suggests, "liberalism might even be defined 
as a systematic attempt to restrict the private abuse of public institutions" (207). The rule of law is not a purely private value.

\section{A Note on the Communitarian Conservatives}

One possible weakness of Holmes' book is that he does not discuss the differences between conservatives and traditionalist liberals, on the one hand, and the communitarian antiliberals, on the other. Some elements of the antiliberal critique might be found in the writings of a theorist who will not adopt the argument wholesale, and thus remains a conservative, or even a liberal. F.A. Hayek, for example, maintains that the mind is a product of accumulated tradition and sees in custom the source of human rationality and ethical obligation. $^{2}$ His political thought, however, is distinctly liberal. Tradition, for Hayek, is a means to material progress because it is more likely to be useful than the products of design. A conservative, such as Russell Kirk, may share the antiliberal's fear of atomization brought on by the market: "it turned the world inside out. Personal loyalties gave way to financial relationships. The wealthy man ceased to be magistrate and patron; he ceased to be neighbor to the poorman; he became a mass-man, very often, with no purpose in life but aggrandizement. ${ }^{13}$ Despite his frustration, Kirk will not condemn the modern West as does the antiliberal; his very conservatism restrains him. Conservatism, as Oakeshott puts it, "is a disposition appropriate to a man who is acutely aware of having something to lose which he has learned to care for; a man in some degree rich in opportunities for enjoyment, but not so rich that he can afford to be indifferent to loss." 4 The conservative may bemoan and even resist change, but he will never seek to destroy what makes the present possible because he wants to retain what is valuable in existing conditions. The antiliberal, on the other hand, sees little of value in the liberal present, strikes at the heart of it and seeks to replace it with some long-forgotten truth. This is central to the antiliberal strategy as Holmes describes it.

Liberal institutions are the products of historical growth, and their development, which marks the gradual realization of liberal values, can be considered political and cultural progress. The rule of law and individual liberty are the legacy of political struggle by groups who sought relief from domination and arbitrary power in constraints on political authority. Because they are the results of conflict, there is nothing inevitable about the emergence of liberal social and political practices. Nevertheless, one can discern a general pattern of development. Herbert Spencer, a neglected figure in the history of political thought, treated the emergence of liberalism as the transformation of "militant" societies, based on status and compulsion, to "industrial" societies, characterized by equal liberty and voluntary cooperation. Militant societies are organized to achieve a collective goal: victory in warfare. Consequently, collectivist values, which subordinate the ends of the individual to those of the group, predominate. (That readiness for war is the collective goal of such societies is less significant than the fact that they are organized for the pursuit of a common purpose). Industrial societies are not organized to pursue collective goals, but instead to facilitate the achievement of individual ends through freedom and competition. Individualist sentiments, which resist encroachments on individual liberty, supersede the collectivist attitudes of preliberal societies. ${ }^{5}$ As a matter of historical fact, the liberal societies we know have developed from what Spencer called the militant type, and 
their transformation has seen the gradual (and imperfect) replacement of collective goals and collectivist values by individual ends and individualist values.

It is precisely this change that is the object of the communitarian antiliberals' disdain. They long for the communal solidarity, collective purpose and altruistic sacrifice of preliberal societies, and in this respect the antiliberals are reactionaries. The point of characterizing them in this way is not to give them an unappealing name, but instead to draw out some of the meaning of their critique of liberal political life and thought. Holmes' suggestion that we view nonmarxist antiliberalism as a mindset or attitude as well as political theory is significant. The collectivist values they wish to resuscitate were, as Hayek suggests, those of our primitive ancestors who were

guided by concrete, commonly perceived aims, and by a similar perception of the dangers and opportunities - chiefly sources of food and shelter - of their environment ... These modes of coordination depended decisively on instincts of solidarity and altruism - instincts applying to members of one's own group but not to others. ${ }^{6}$

Hayek argues that these primitive collectivist dispositions lay behind intellectual arguments on behalf of socialism and redistributionism, and he maintains that these are atavisms. Once economic development gives rise to a complex division of labor that supports a large population, the individual pursuit of self- chosen goals becomes necessary for group survival, and the collectivist mores of preliberal societies can no longer provide the basis for a viable social order. ${ }^{7}$ The mindset that Holmes attributes to the antiliberals is similarly atavistic. The values antiliberals wish to substitute for the liberal ethos were the cultural products of preliberal societies. When they express admiration for the communal solidarity of ancient Greece and medieval Europe, the antiliberals are simply praising the sentiments that supported militant societies. In their appeal to these sentiments and values, the communitarian antiliberals are reactionary.

Recognizing the reactionary nature of the antiliberal critique adds another perspective on the weakness of the communitarian alternative. If it is true that group purpose and consciousness are essential to human well-being, then the policy proposals suggested by some of the soft antiliberals, such as "tightening up pornography laws," are much too mild (181). If community can be helped along by cautious tinkering, liberalism does not have a serious problem, even by communitarian standards. If, on the other hand, the realization of communitarian values demands that individual ends be subject to collective control, communitarians must answer the same practical questions that present difficulties to socialists. It may turn out that we need individualism and markets whether we like them or not.

Scott Boykin, University of Alabama at Birmingham 


\section{Notes}

1. All page references are to Holmes' book.

2. F.A. Hayek, Law, Legislation and Liberty, vol. 1: Rules and Order (Chicago: University of Chicago Press, 1973), 17-19.

3. Russell Kirk, The Conservative Mind 7th ed. (Chicago: Regnery, 1986), 228.

4. Michael Oakeshott, Rationalism in Politics and Other Essays, with a foreword by Timothy Fuller (Indianapolis: Liberty Fund, 1991), 408.

5. Herbert Spencer, The Principles of Sociology, 3 vols (New York: D. Appleton, 1900), 2:568-642.

6. F.A. Hayek, The Fatal Conceit (Chicago: University of Chicago Press, 1988), 11-12.

7. F.A. Hayek, New Studies in Philosophy, Politics, Economics, and the History of Ideas (Chicago: University of Chicago Press, 1978), 57-68. 


\section{References}

Bovard, James. Lost Rights: The Destruction of American Liberty. New York: St Martins Press, 1992.

Brooks, Stephen and Alain-G Gagnon, eds. The Political Influence of Ideas: Policy Communities and the Social Sciences. Westport, Connecticut: Praeger, 1994.

Burke, T. Patrick. No Harm: Ethical Principles for a Free Market. New York: Paragon House, 1994.

Cook, John W. Wittgenstein's Metaphysics. Cambridge: Cambridge University Press, 1994.

Crittenden, Jack. Beyond Individualism: Reconstituting the Liberal Self. New York: Oxford University Press, 1992.

Harris, Errol E. The Reality of Time. Albany: State University of New York Press, 1988.

Jaffa, Harry V. et al. Original Intent and the Framers of the Constitution: A Disputed Question. Washington, DC.: Regnery Gateway, 1994.

Martin, Rex. A System of Rights. Oxford: Clarendon Press, 1993.

Neville, Robert Cummings. The High Road Around Modernism. Albany: State University of New York, 1992.

Rowley, Charles K. ed. Property Rights and the Limits of Democracy. Hants, England: Edward Elgar Publishing Limited, 1993.

Spector, Horacio. Autonomy and Rights: The Moral Foundations of Liberalism. Oxford: Clarendon Press, 1992.

Timmons, Mark. Conduct and Character: Readings in Moral Theory. Second edition. Belmont, California: Wadsworth Publishing Company, 1995.

White, Morton. The Question of Free Will: A Holistic View. Princeton: Princeton University Press, 1993.

Wood, Denis and Robert J. Beck. Home Rules. Baltimore: James Hopkins University Press, 1994.

Yates, Steven. Civil Wrongs: What Went Wrong with Affirmative Action. San Francisco: ICS Press, 1994. 